\title{
Középkori kínai források Mekkáról és Medináról
}

Kína és az iszlám viszonyát két oldalról lehet megközelíteni: egyrészt vizsgálható az iszlám története a középkori vagy modern kori Kínában, másrészt elemezhetőek a Kínán kívüli iszlámról szóló kínai források. Az első témát viszonylag sokan körbejárták már, ${ }^{1}$ jelen írásomban a másodikat vizsgálom. ${ }^{2}$

A témát még két szempontból tovább szükítettem. Egyrészt jelen írásban nem tanulmányozom, hogy a kínai muszlim írástudók mit tudtak saját vallásukról, ${ }^{3}$ ehelyett arra koncentrálok, hogy kínai utazók (akik között akadtak muszlimok is, mint például Ma Huan) és írástudók milyen információkkal rendelkeztek erről a vallásról. Másrészt időben és térben elsősorban az iszlám kialakulásáról és alapvető tanításáról szóló forrásokat elemzem, nem foglalkozom a későbbi iszlámmal kapcsolatos beszámolókkal. Alapvetően tehát a kínai útibeszámolókban, történeti és földrajzi munkákban megőrzött, korai iszlámra vonatkozó feljegyzések fontosabb témáit mutatom be.

\section{A források}

Az iszlámra vonatkozó kínai nyelvü történeti forrásaink kronológiai sorrendben a következők:

1. Du Huan 杜環 (fl. 761): Jingxingji 經行記. Du You 杜佑 (735-812) 801-re elkészült Tongdian 通典 címü müvének 193. fejezete a dashikről

* MTA-ELTE-SZTE Selyemút Kutatócsoport, ELTE BTK.

1 Magyarul Oláh 2000, angolul például Israeli 1978, 1994, Leslie 1986, Ben-Dore Benite 2005.

2 Köszönöm Szombathy Zoltánnak (ELTE BTK Sémi Filológiai és Arab Tanszék), hogy a kézirattal kapcsolatban megfogalmazta javaslatait.

3 A Kínában élő, a konfucianizmust és az iszlámot összeegyeztetni kívánó 17-18. századi írástudók (pl. Liu Zhi 劉智, Wang Daiyu 王岱塞) műveiről (ún. Hān Kitāb) legutóbb lásd Wain 2016, Petersen 2017. 
(arabokról) szól, benne szerepel Du Huan 杜環 saját megfigyelésein alapuló leírása (Jingxingji 經行記). ${ }^{4}$

2. Jiu Tangshu 舊唐書 (A Tang-dinasztia régi története) és Xin Tangshu 新唐書 (A Tang-dinasztia új története): a Tang-dinasztiáról (618-907) szóló hivatalos történeti munkák (zhengshi 正史). Az előbbit Liu Xu 劉凅 és Zhang Zhaoyuan 張昭遠 vezetésével szerkesztették a 10. században, az utóbbit egy Ouyang Xiu 歐陽修 és Song Qi 宋祁 vezette csoport szerkesztette a 11. században.

3. Zhou Qufei 周去非 (12. sz.) Lingwai daida 嶺外代答 (Válaszok a hegyeken túli vidékekröl) címü földrajzi munkája 1178-ból.

4. Zhao Rugua 趙汝适 (1170-1228) Zhufanzhi 諸蕃志 (Beszámoló a külföldi országokról) címü földrajzi munkája 1225-böl. ${ }^{5}$

5. Zhou Zhizhong 周致中 (14. sz.) Yiyuzhi 異域志 (Beszámoló különbözö vidékekröl) címü földrajzi munkája.

6. Ma Huan 馬歡 Yingya shenglan 瀛涯勝覽 (Az óceán partjainak átfogó tükre) címủ müve, melynek nagy részét a Zheng He-vel közös utazása alapján írta meg 1433-ban, és 1451-ben publikálta. ${ }^{6}$

7. Mingshi 明史: a Ming-dinasztiáról (1368-1644) szóló hivatalos történeti munka (zhengshi), melynek szerkesztését 1679-ben kezdte el a Xu Yuanwen 徐元文 és mások által vezetett csapat, de csak 1739-ben fejezték be Zhang Tingyu 張廷玉 és munkatársai.

8. Gong Zhen 琿珍 Xiyang fanguo zhi 西洋番國志 (Beszámoló a nyugati óceán idegen országairól) címü munkája, melyet Zheng He-vel közös utazása alapján írt 1434-ben.

9. Fei Xin 費信 Xingcha shenglan 星槎勝覽 (A csillagokba tartó hajó csodálatos felfedezései) címú munkája, melyet Zheng He-vel közös utazása alapján írt 1436-ban. ${ }^{7}$

10.Huang Xingzeng 黃省曾 Xiyang chaogong dianlu 西洋朝貢典錄 $(\mathrm{Fel}$ jegyzések a nyugati óceán adófizetőiről) címü földrajzi müve 1520-ból.

11. Yan Congjian 嚴從簡 Shuyu zhouzi lu 殊域周次錄 (A különféle vidékek átfogó vizsgálatáról készült feljegyzés) címü földrajzi munkája 1574-ből.

Angol fordítása: Akin 1999-2000.

Angol fordítása: Hirth - Rockhill 1910.

Angol fordítása: Mills 1970.

Angol fordítása: Mills - Ptak 1996. 
A rendelkezésünkre álló forrásokat áttekintve jól látható, hogy ezek száma a Ming-korban megnő, aminek oka nyilvánvalóan az, hogy a 15. század első harmadában a megnövekedett számú hajóutak és az egyre intenzívebbé váló külkereskedelem miatt különösen nagy érdeklődésre tartottak számot az arab országokról szóló információk. ${ }^{8}$ A legismertebb tengeri utazó Zheng He 鄭和 (1371 - ca. 1433) muszlim eunuch volt, aki (útjától függően) 90-200 hajóból álló flottájával mintegy 30 országba jutott el. A Ming-dinasztia Yongle 永樂 (1403-1425) és Xuande 宣德 (1425-1435) időszaka alatt hét hatalmas tengeri expedíció indult Kanton, Quanzhou 泉州 és Fuzhou 福州 kikötőiből. A számos helyet (Champa Királyság, Jáva, Szumátra, Ceylon, Sziám, Malaka, Perzsa-öböl, Arab-félsziget, Afrika keleti partja) érintő tengeri expedíciók révén a Ming birodalom politikai, kereskedelmi és katonai tekintélyt szerzett magának. A Ming udvar tudatosan választotta a muszlim Zheng He-t vezetöül, hiszen a megcélzott területeken az iszlám már vagy elterjedt, vagy egyre inkább teret hódított. A fent említettek közül Ma Huan, Gong Zhen és Fei Xin kísérték el Zheng He-t egyik vagy másik útjára, és beszámolójuk jelentős része innen származik. A hivatalos történeti müben (Mingshi) rögzített beszámoló közvetett módon szintén Zheng He utazásához kapcsolódik, hiszen elsősorban Ma Huan információin alapul.

Hozzá kell azt is tennünk, hogy a fenti beszámolók jelentős részét természetesen nem a vallás bemutatása teszi ki, hanem az adott terület földrajzát, klímáját, történelmét, szokásait és leginkább jellegzetes terményeit mutatják be, a vallás tehát csak egyike a számos érintett témának.

\section{A beszámolókban említett főbb témák}

A következökben a fenti leírásokban megörzött témákat mutatom be és elemzem röviden. Az egyszerüség kedvéért az egyes idézetek után a következő rövidítésekkel utalok a fenti művekre:

JXJ: Jingxingji 經行記 (Tongdian, SKQS ed.);

JTS: Jiu Tangshu 舊唐書 (SKQS ed.);

XTS: Xin Tangshu 新唐書 (SKQS ed.);

ZFZ: Zhufanzhi 諸蕃志 (SKQS ed.);

LDD: Lingwai daida 嶺外代答 (SKQS ed.);

YYZ: Yiyuzhi 異域志 (online ed.);

8 Pelliot 1933. 
YSL: Yingya shenglan 瀛涯勝覽 (Wan 2005 ed.);

MSH: Mingshi 明史 (SKQS ed.);

XFZ: Xiyang fanguo zhi 西洋番國志 (online ed.);

XSL: Xingcha shenglan 星槎勝覽 (online ed.);

XCD: Xiyang chaogong dianlu 西洋朝貢典錄 (online ed.);

SZL: Shuyu zhouzi lu 殊域周咨錄 (Xu 2000 ed.).

\subsection{Mekka és Medina}

Érdemes az alapvető elnevezésekkel kezdeni: a korai, Tang-kori források többsége az arab területeket a Dashi 大食 elnevezéssel illeti, ami a legvalószínủbb etimológia szerint a perzsa $t \bar{a} z \bar{\imath}$ ('arab') szóból ered, ${ }^{9}$ bár van olyan vélemény is, hogy az arab tājir („,kereskedő”) szó kínai átírása. ${ }^{10}$ Az Omajjád kalifátust (al-Khilāfa al-'Umawiyyah, 661-750) például ,fehér ruhás araboknak” (Baiyi Dashi 白衣大食), az “Abbászidákat (al-Khilāfa al-'Abbāsīyah, 750-1258) pedig „fekete ruhás araboknak” (Heiyi Dashi 黑衣大食) nevezték a kínai források. ${ }^{11}$ Ugyanakkor a dashi kifejezés elsősorban az iszlám által meghódított területekre vonatkozott, így nagyon gyakran nem arabokat, hanem például muszlim vallású perzsákat vagy más belső-ázsiai népeket jelölt.

A források leginkább Mekkát említik, ezt gyakran nem városnak, hanem államnak (guo 國) tekintve: Mojia 糜嘉 (LDD), Mojia 摩迦 [Songhuiyao jigao: fanyi 7, 宋會要輯稿, 蕃夷 7], Muqi 穆齊 [MSH], illetve Tiantang 天堂 (MSH, YSL, XFZ, XCD) vagy Tianfang 天方 [YSL, MSH, SZL]. Az első három elnevezés fonetikus átírás, tehát a Mekka szó két szótagjának középkori kínai kiejtéssel történő visszaadása, illetve ennek leírása különböző írásjegyekkel: Ma- [ma:] 麻 / Mo [mua] 摩/ Mo [məwk] 穆 ${ }^{12}$; jia [kja:] 嘉, jia [kia] 迦, jia [tshjiaj] 齊13, tehát a késő középkori alakok: Ma:-kja:, Mua-kia, Məwk-tshjiaj. A második típus már kulturális fordítás: a későbbiekben még említendő Kába kínai elnevezését (Tiantang vagy Tianfang) fontossága miatt alkalmazták magára a városra, illetve az államra is. A kétfajta elnevezés azonosságát néhány forrás explicit módon hangsúlyozza is:

\footnotetext{
9 Bretschneider 1910a: 265.

$10 \mathrm{Hu}$ 2008: 16. n. 43.

11 Hu 2008: 16. n. 43.

12 Pulleyblank 1991: 206, 217, 218.

13 Pulleyblank 1991: 143.
} 
„Kába állam nem más, mint Mekka állam.” (YSL [99]: 天方國, 即 默伽國也。)

„Kába államot, amely korábban Yunzhong ${ }^{14}$ földje volt, egyesek Kábának, mások pedig Mekkának nevezik.” (MSH [332.29b]: 天方, 古 筠冲地, 一名天堂, 又曰穆齊。)

Medina kínai neve ennél csak jóval később és ritkábban fordul elő, ebben az esetben kizárólag a fonetikus átírás típusa jelenik meg: Modena 默德那 (muj-təj-no) ${ }^{15}$ [MSH, Yitongzhi 一統志], illetve Modina 驀底納 (maj-ti-na) ${ }^{16}$ (YSL, XFZ, XCD), ugyanakkor ezt ezek a források kizárólag városként (cheng 城) említik.

\subsection{Szokások}

A források többsége (JXJ, YSL, MSH, XFZ, XCD) kiemeli azt a kínaiak számára furcsa szokást, hogy a nők eltakarják az arcukat. Ezt jelenleg talán inkább vallási előírásként tartanánk számon, ${ }^{17}$ ugyanakkor a kínai források (az eredeti, közel-keleti funkciójának megfelelően) egyszerü öltözködési jellegzetességként mutatják be, és nem tulajdonítanak neki semmilyen vallási hátteret.

„Amikor egy nő elhagyja otthonát, feltétlenül betakarja az arcát." (JXJ [193.29a]: 女子出門, 必擁蔽其面。)

„A nők mind fátylat [fej-takarót] hordanak, így nem lehet látni az arcukat.” (YSL [99]: 婦人俱戴蓋頭，不見其面。)

„A nők befonva hordják a hajukat, és eltakarják a fejüket, nem fedik fel az arcukat.” (MSH [332.33a]: 婦女則徧 [辫 ${ }^{18}$ 髪蓋頭, 不露其 面。)

14 Jost (2008: 111) szerint ez Medina korábbi nevének (Yatrib) átírása.

15 Pulleyblank 1991: 218, 74, 221.

16 Pulleyblank 1991: 218, 75, 221.

17 Erröl magyarul lásd például Simon 2009: 149-152.

18 Wang Dayuan 汪大淵 Daoyi zhilüe 島夷志略 (1339) címủ műve rendkívül szűkszavúan beszélve erről a vidékről említi, hogy a férfiak és a nők is befonva hordják a ha-

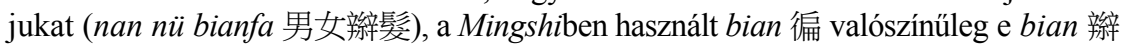
helyett áll. 
„A nők letakarják a fejüket, így aztán nem lehet látni az arcukat.” (XFZ [天方國]: 婦人蓋頭，卒不能見其面。)

„A nők letakarják a fejüket, az arcuk nem látszik.” (XCD [23.C7]:

女蓋首, 面不露。)

A fej, illetve az arc eltakarására használt gaitou 蓋頭 a kínai házassági szertartás során a menyasszonyt rövid ideig eltakaró, általában piros színủ ruhadarab (hong gaitou 紅蓋頭) volt, és ez a muszlim szokásoktól függetlennek tünik. Ugyanakkor ugyanezt a gaitou szót a Kínában élő muszlimok ma is alkalmazzák a hidzsábra, ${ }^{19}$ habár a fenti leírás megfelelője nem az arcot éppen látni engedő hidzsáb (hijāb), hanem az azt a szemek kivételével eltakaró nikáb (niqāb), amelynek jelenlegi, modern kínai megfelelője viszont az arab szó átírása (nikabu 尼卡布).

Szintén inkább általános szokásként és nem vallási előírásként kezelik a kínai történeti források az alkoholfogyasztás tilalmát. ${ }^{20}$ Három helyen (YSL, XFZ, XCD) ezt az arab nyelv (alabiya yu 阿剌必言語) használata után említik, és országos szintü szabályozásról vagy törvényről (guofa 國法) beszélnek. További két hely (JXJ, XTS) az alkohol tilalmát összekapcsolja a zene tiltásával.

„Az alkohol ivásának véget vetettek, betiltották a zenét.” (JXJ [193.29a]: 聯飲酒, 禁音樂)

„Nem isznak alkoholt, nem zenélnek.” (XTS [221B.23a]: 不飲酒舉樂)

„Országos szintű törvény tiltja az alkoholt.” (YSL [100], XFZ [天方 國]: 國法禁酒)

„Szokásuk szerint betiltják az alkoholt.” (MSH [332.33b]: 俗禁酒)

„(Abban) az országban [Mekka] alkoholtilalom van.” (XCD [23.C7]: 國有酒禁)

\subsection{Ima}

A kínai forrásokban a fentiekhez képest jóval kisebb figyelmet kapnak az imák. Habár több kínai szó is van az imára ( $q i$ 祈, dao 禱), ezeket egyszer sem ne-

19 Erie 2016: 214, 358.

20 Az alkoholtilalomról az iszlámban magyarul röviden lásd Simon 2009: 38-39. 
vezik így, hanem tiszteletadásnak, szertartásnak ( $l i$ 禮) hívja a legkorábbi forrás (Du Huan: Jingxingji), míg a meghajlás, leborulás aspektusát emelik ki a későbbi szövegek ( $b a i$ 拜). A bai 拜 az ókortól kezdve tiszteletet, tiszteletteljes köszönést fejez ki az ezt kísérő mozdulatot (derékkal történő meghajlást, teljes leborulást) is beleértve, és így jó (bár természetesen nem teljesen pontos) megfelelöjének tünik a rak'ah-nak (,,ima-egység"), ${ }^{21}$ illetve ezen belül a muszlim hívők által gyakorolt meghajlásnak [rukú',rukū '], valamint a leborulásnak (szudzsúd, sujūd).

„Egy napon öt (kijelölt) alkalommal fejezik ki tiszteletüket az Égnek.” (JXJ [193.29a]: 一日五時禮天。)

„Egy napon ötször fejezik ki leborulással tiszteletüket az Ég Szelleme (Istene) előtt.” (XTS [221B.23a]: 日五拜天神。)

„Minden nap ötször fejezik ki leborulással tiszteletüket az Ég előtt.” (ZFZ [A.27]: 每日五次拜天。)

A fenti részletekben a hangsúly mindhárom esetben azon van, hogy ez a tiszteletadás ötször történik. A legkorábbi forrásban (JXJ) jelzik talán a legpontosabban, hogy itt egy megfelelő, meghatározott időben (wushi 五時) bemutatott tiszteletadásról van szó, míg a későbbi források pusztán az ötszöri alkalmat említik. A tiszteletadás címzettje az összes forrásban az Ég (tian 天), ez értelemszerüen Allahra vonatkozik. Két későbbi szövegben említik, hogy ez a tiszteletadás nyugat felé történik.

„Mindennap nyugati irányba borulnak le tisztelettel.” (MSH [332.34b]:

[Medina] 每日西向虔拜。)

„Mindennap nyugati irányba fejezik ki tiszteletüket az Ég előtt.” (SZL [11/默德那.391]: 每日西向拜天。)

Bár mindkét leírás a Medinára vonatkozó részben található, ehhez képest Mekka délre lenne, tehát az imairány (kibla, qibla) inkább arra látszik utalni, hogy a beszámoló szerzői belső-ázsiai vagy még inkább kínai muszlimokra gondoltak, hiszen számukra mindenféleképpen nyugatra van Mekka.

21 Simon 2009: 338, illetve 364 . 


\title{
2.4. Étkezési előírások
}

Az étkezési előírásokat illetően a disznóhús tiltását három forrás említi, ezek közül a legkorábbi ezt kiegészíti a kutya-, szamár- és lóhús fogyasztásának tilalmával (harám, harām).

„Nem esznek a disznó, a kutya, a szamár, a ló és még további (állatok) húsából.” (JXJ [193.15a]: 不食猪狗驢馬等肉。)

„Nem esznek disznóhúst.” (MSH [332.35a]: 不食豬肉。)

„Nem esznek disznóhúst.” (SZL [11/默德那.391]: 不食豕肉。)

Egy másik visszatérő motívum értelmezése vitákat váltott ki, de valószínűsíthető (különösen a lenti SZL részletből), hogy ez az ételek elkészítésének sajátos szabályaira vonatkozik, tehát a halál (halāl, ,megengedett”) állatok megölésére vonatkozó ún. dzabiha (dhabihhah, „vágási”) elöírásokra utal.

\begin{abstract}
„A húsevéshez tisztítási szertartást végeznek, az élölények megölését érdemszerző erénynek tartják.” (JXJ [193.29a]：食肉作齋, 以殺生為 功德。)
\end{abstract}

„Általában nagy hangsúlyt fektetnek [figyelmet fordítanak] az (állatok) megölésére.” (MSH [332.35a]: 俗重殺。)

„Különösen nagy hangsúlyt fektetnek az (állatok) megölésére, ha nem ugyanolyan típusú [muszlim] ember vágja, akkor nem eszik meg." (SZL [11/默德那.391]: 人尤重殺, 非同類殺者不食。)

A fenti mondatok tehát valószínüleg arra vonatkoznak, hogy csak olyan állat húsát szabad megenni, amelyet szándékosan vágtak le, vagyis fontosnak számít az állatok levágásának gyakorlata, a saját magától elpusztult állatokat nem eszik meg: „Csupán a döglött állat [húsát] tiltotta meg nektek ...”"22 (Korán 2:173); „Tilalmas nektek a döglött állat [húsa] (...) a [zuhanás miatt] halálra zúzódott, a [más állattól] felöklelt, a vadállatoktól szétmarcangolt [állatok húsa] - kivéve, ha [még nem szenvedtek ki és] ti vágjátok le azokat..."23 (Korán 5:3).

22 Simon R. (1987a: 21) ford.

23 Simon R. (1987a: 75) ford. A datáláshoz lásd Simon 1987b: 135. 


\section{5. Ünnepek (Péntek, Ramadán)}

Mindösszesen két forrás utal a hét egyik napjának kitüntetett jellegére, ami az iszlám esetében a péntekre kell, hogy vonatkozzék. A korai Jingxingji kissé furcsán fogalmaz, amikor az alkoholfogyasztást megengedhetőnek véli pénteken, és semmilyen kötelességet nem említ ezen a napon. A Lingwai daida jóval pontosabb, amikor az afganisztáni Ghazniban látott muszlim péntekkel kapcsolatban mecsetbeli szertartást (pénteki ima, szalát al-dzsum 'a, șalāt aljum 'ah) említ, sőt a dzsum 'a szót két kínai átírásban (chu 除, chumie 廚茷) meg is adja.

„Szokás közöttük, hogy minden hét napból egy szabad, (ilyenkor) nem kereskednek, nem nyúlnak pénzhez, csak bort isznak, és incselkedő semmittevéssel töltik az egész napot.” (JXJ [193.15a]: 其俗每七日 一假，不買賣，不出納，唯飲酒謔浪終日。)

[Ghazni] „Az ebben az államban élő emberek hét naponta egyszer elmennek a csarnokba [mecsetbe], hogy ott vallási szertartáson vegyenek részt, ezt (a napot) chunak vagy chumienek hívják." (LDD [3.3b]: [吉慈尼國]國人七日一赴堂禮拜，謂之除或作廚喓。)

Az eredetileg vásárnapnak számító pénteken $(d z s u m$ 'a, jum 'a) délben jöttek össze a hívek a mecsetben, de utána kora délutánig a piacon voltak, ezért figyelmeztet a Korán (72:9-11), hogy az istentiszteletet ne hagyják ott a kereskedés és a szórakozás kedvéért. ${ }^{24}$

A második idézetben említett csarnok a Jingxingjiben a 'szertartás csarnokaként' (litang 禮堂) szerepel, és ezt a mecsetet ez a korai forrás és az ezt alapul vevö Xin Tangshu is hatalmasként írja le:

„Van ott még egy szertartási csarnok [mecset], amely több tízezer embert tud befogadni.” (JXJ [193.29a]: 又有禮堂, 容數萬人。)

24 Simon 1987a: 405, Goitein 1991: 593a. Ugyanakkor, ha a kínai leírást az éjszakára értelmezzük (és nem az egész napra), akkor a leírás (kereskedelem tiltása, szórakozás) inkább hasonlít a Ramad̄an gyakorlatára: „Trade and industry are largely at a standstill during Ramadan (...) As sleeping is not forbidden during the fast, they often sleep a part of the day; and the night, in which one may be merry, is given up to all sorts of pleasures. In particular, the nights of Ramadan were formerly the time for public entertainments, the shadow play (...) and other forms of the theatre" (Plessner 1995: 418a). 
„Van ott egy szertartási csarnok [mecset], amely több tízezer embert tud befogadni.” (XTS [221B.23a]: 有禮堂容數百人。)

Ahogy a fenti leírás a muszlim hét kitüntetett napjára utalt, úgy a következők a muszlim év ünnepi hónapjára, a Ramadánra (Ramaḍ̄n) vonatkoznak. ${ }^{25}$

„Az év kezdetén egy hónapon keresztül tisztulási böjtöt tartanak, és szent könyvet recitálnak.” (ZFZ [A.27]: 歲首清齋念經一月。)

„Minden évben egy hónapig böjtölnek, és megfürödve ruhát cserélnek.” (MSH [332.34b]; SZL [11//默德那.391]: 每歲齋戒一月, 沐浴 更衣。 $)^{26}$

A Ramadán alatt szokás (de nem kötelezö) elvégezni az ún. taráwíh (tarāwīh) imákat, ezek keretében a teljes Koránt recitálják, amelyet tehát a Ramadán 30 éjszakájának megfelelően 30 részre ( $d z s u z$, juz') osztottak fel. ${ }^{27}$ A napközbeni böjt közismerten szerves részét képezi a Ramadánnak, a fürdés pedig minden bizonnyal az imákhoz, illetve a Korán recitálásához szükséges rituális tisztaság állapotába (táhir) kerülést szolgáló kisebb (wudú, wuḍu') vagy nagyobb (ghuszl, ghusl) mosdásra utal, attól függően, hogy az illető milyen nagyságú tisztátalanság állapotába került korábban. ${ }^{28}$

\subsection{Törvények szigorú betartása}

A fent említett (nikáb, alkoholtilalom, étkezési előírások, péntek, Ramadán), illetve egyéb, nem részletezett szabályokkal (házasság, temetés) kapcsolatban a legtöbb forrás megjegyzi, hogy ezeket a muszlimok rendkívül szigorúan betartják, és alig van olyan, aki megszegné ezen elöírásokat.

„Még a szegényen és nehéz körülmények között élő családok is mind betartják a vallás elöírásait, kevesen vannak, akik vétenek a törvény

25 Erről magyarul lásd Simon 1987b: 53-55, Simon 2009: 339-340.

26 Lényegében ugyanez a mondat megjelenik egy mecset feliratán is, Wu Jian 吳鑒 (fl. 1349-1351): Qingjingsi ji 清靜寺記 [1350]: 每嵗齋戒一月，更衣沐浴.

27 Wensinck 2000.

28 Lásd Szombathy 2018. A fenti két esetben használt kínai kifejezés (muyu 沐浴) első fele eredetileg a hajmosásra utal, ami talán megfeleltethető a $w u d \underline{u}$ ' elsősorban fejet és kezet érintő mosdásának, a $y u$ 浴 pedig talán inkább a teljes testet érintő ghuslmosdással analóg. 
ellen, ez tényleg maga a 'legnagyobb boldogság világa'29 . A házassági és temetési szertartásaikat mind a (muszlim) tanítás szerint rendezik és végzik.” (YSL [100]: 雖貧難之家，悉遵教規，犯法者少，誠為 極樂之界。婚袁之禮, 皆以教門體例而行。)

„Az emberek közül kevesen vétenek a törvény ellen. Nincsenek szegény vagy nehéz körülmények között élő családok. A házassági és temetési szertartásaikat mind a muszlim tanítás szerint végzik." (XFZ [天方國]: 人少犯法。無貧難之家。其婚䘫禮皆回回教門。)

„A házasságokat és a temetéseket mind a muszlim szertartások szerint végzik.” (XCD [23.C7]: 其婚喪悉行回回禮。)

Néhány forrás kiemeli, hogy a muszlimok akkor sem változtatnak a szokásaikon, ha egy másik országba, és ezzel együtt nyilván más vallási környezetbe költöznek.

„Még ha egy másik országba mennek is, akkor sem változtatják meg a szokásaikat.” (MSH [332.35a]: 雖適他邦，亦不易其俗。)

„Az ebben az országban élők tisztelettel hisznek a vallásukban, és még ha egy másik vidékre mennek is, átadják azt fiaknak és unokáiknak, és generációkon át sem változtatnak rajta.” (SZL [11/默德那.391]: 國人尊信其教, 雖適殊域, 傳子孫累世不敢易。)

\subsection{Korán}

Kizárólag a kései forrásokban és ezek közül is csak kettőben (MSH, SZL) szerepel a Koránra történő utalás: mindkettő a Korán felosztását említi:

„[Medina] államában van egy szent könyv, 30 részes, összesen több mint 3600 szakasz.” (MSH [332.34b]: 國中有經三十本，凡三千六 百餘段。)

„A szent könyvük 30 egységből áll, összesen több mint 3600 részből [tekercsből].” (SZL [11/默德那.389]: 其經有三十藏，凡三千六百 餘卷。)

29 A 'legnagyobb boldogság világa' (jile zhi jie 極樂之界) egy a Tiszta Föld buddhizmushoz tartozó kifejezés, a szanszkrit Sukhāvatī kínai megfelelője. 
A Korán szövegének 30 egységre ( $d z s u z$, juz'; pl. adzszá', ajzāa') történő felosztása általános gyakorlat az iszlámban, amelynek hasznossága leginkább a 30 napos Ramadán során érvényesül. ${ }^{30}$ Ugyanez a 30-as felosztás megtalálható a Ming-dinasztia első császárának (Ming Taizu 明太祖 vagy Hongwu 弘武 [1368-1398]) tulajdonított Baizizan 百字讃 című versben: „A vallást közvetítő nagy szent megszületett a nyugati vidéken. Megkapta az égi írást, amely 30 részböl állt" (傳教大聖, 降生西域。授受天經, 三 十部冊). ${ }^{31}$

Itt érdemes megemlíteni, hogy a Wu Jian 吳鑒 (fl. 1349-1351) által 1350-ben írt, Quanzhou-beli mecsetfelirat (Qingjingsi ji 清靜寺記) a második forrásban használt kifejezéshez hasonlóan említi a 30-as felosztást (sanshi zang 三十藏), de ezen kívül 114 részre (yibai yishi si bu一百一十四部) utalva a szúrák számát is tartalmazza, valamint 6666 „tekercset” (liuqian liuban liushi liu juan 六千六百六十六卷) különböztet meg. ${ }^{32}$ Ez utóbbi egy elterjedt nézetet tükröz, amely szerint a Koránban ennyi vers (ája, āyah) található $^{33}$ (valójában ennél kevesebb van), feltehetően ennek elírása (liu 六 helyett san 三) a fent szereplö „több mint 3600 egység”, mivel ez utóbbi nem szokásos felosztása a Koránnak. ${ }^{34}$

Furcsa módon az egyes felosztásokra használt kínai kifejezésekből úgy tünik, a felirat szerzője azt a benyomást kívánta kelteni, mintha a muszlimok szent könyve nagyságrendileg a buddhista kánonhoz hasonlítana vagy azt akár felül is múlná. Erre utal, hogy a három kosárból (zang 藏) álló buddhista kánonnak megfelelően ebben a feliratban a Korán áll 30 kosárból, a 6666 után pedig nem a „vers” szó kínai megfelelöje, hanem a könyvtekercs (juan 卷) szó áll, miközben az 1372-1402 között császári rendeletre összeállított buddhista kánon (Hongwu Nanzang 洪武南藏) hozzávetőlegesen 7000 tekercsből áll. ${ }^{35}$

\footnotetext{
Gade 2006: 486.

Leslie 1987: 192.

Leslie 1987: 192.

Az ája fogalmáról lásd Simon 2009: 270-271, Neuwirth 2006.

Szombathy Zoltán szíves közlése.

Long 2000: 116.
} 


\subsection{Harci erények}

A legkorábbi Jingxingji két érdekes információt is közöl, amelyek szerint heti egyszer maga az uralkodó is részt vesz a szertartáson (valószínúsíthetően a máshol sem konkretizált pénteki alkalmakról van szó), ahol ő maga mond beszédet. E beszédekben az általános erkölcsi értékek mellett a harctéren tanúsított bátorság és önfeláldozás túlvilági jutalmát hangsúlyozza, a Xin Tangshu pedig ennek a felfogásnak tulajdonítja az arabok harci bátorságát.

„Minden hetedik napon az uralkodó is részt vesz a szertartáson, felmegy a magas emelvényre, és a tömegeknek így hirdeti a tant: »'Az emberi élet rendkívül nehéz, az égi út nem változik: nincs nagyobb bün, mint ha a következő (bünökből) akár csak egyet elkövetsz: bujaság és rablás, zsugoriság és rágalmazás, saját magunknak kedvezni és másokat veszélybe sodorni, becsapni a szegényeket és sanyargatni az elnyomottakat.' Mindenki, aki háborúba megy és az ellenség által meghal, biztosan a mennybe jut, aki pedig megöli az ellenséget, annak boldogsága végtelen lesz.«” (JXJ [193. 29a]: 每七日, 王出禮 拜, 登高座為眾說法曰：「《人生甚難, 天道不易。奸非劫㯖, 細行謾言, 安已危人, 欺貧虐賤, 有一於此, 罪莫大焉。《凡有 征戰, 為敵所翏, 必得生天, 殺其敵人, 獲福無量。」)

„Hétnaponként az uralkodó magasan ülve így magyaráz a lent lévőknek: »Aki az ellenség által hal meg, a mennybe jut, aki megöli az ellenséget, az boldogságot szerez.« Ezért ilyen bátrak általában a harcban.” (XTS [221B. 23a]: 率七日, 王高坐為下說曰：「死敵者生 天上, 殺敵受福。」故俗勇於鬥。)

Az itt említett 'magas emelvénnyel' (gaozuo 高座) kapcsolatban Ibn Baț̣uțah megjegyzi, hogy azt a Kába-szentély oldalához tolták péntekenként, majd az állva elmondott és két részre osztott prédikáció (khutba, khuṭbah) végeztével eltolták onnan. ${ }^{36} \mathrm{~A} k h u t b a h$-t a mai napig ajánlott valamilyen pulpituson vagy emelvényen elmondani. ${ }^{37} \mathrm{~A} k h a t ̦ i ̄ b$ (prédikáló személy) régebben lehetett uralkodó is, illetve ha más mondta a khuṭbah-t, az uralkodót szokás volt megemlíteni benne. ${ }^{38}$

\footnotetext{
36 Boga - Prileszky 1964: 78, Gibb 1958: 231-233.

37 Wensinck 1986: 74a.

38 Köszönöm Szombathy Zoltánnak az információt. A khuṭbah-ról lásd Qutbuddin 2008.
} 


\subsection{Monoteizmus}

Majdnem mindegyik forrás megemlíti, hogy a muszlimok kizárólag az Eget tisztelik, ebben az esetben joggal feltételezhetjük, hogy a hagyományos kínai felfogásban a legfelsőbb erőként funkcionáló Ég (tian 天), illetve később a buddhizmusban az isteni erők (szanszkrit deva) fordítására használt szó valójában Allah helyett áll, tehát a monoteizmus leírásáról van szó.

„Kizárólag az Égnek áldoznak.” (JXJ [193.15a]: 祀天而已。)

„Előszeretettel szolgálják az Égi Szellemet.” (JTS [198.35b]: 好事天 神。)

„Azt mondják, hogy saját országukban kizárólag az Égi Szellemet imádják [előtte borulnak le]." (JTS 198.36b: 自云在本國惟拜天 神。)

„Oszágukban kizárólag az Eget imádják [előtte borulnak le].” (XTS [221B.24a]: 國人止拜天。)

„Az uralkodó, a hivatalnokok és a nép mind az Eget szolgálja.” (ZFZ [A.27]: 王與官民皆事天。)

„Az állam uralkodója, a hivatalnokok és a nép mind az Eget szolgálja.” (LDD [3.2b]: 國王官民皆事天。)

„Tanításuk szerint az Ég szolgálata a legfőbb, és nem állítanak képmásokat.” (MSH [332.34b]: 其教以事天為主, 而無像設。 $)^{39}$

Egyes források jól láthatóan ugyanezzel a felfogással magyarázzák azt, hogy a muszlimok nem borulnak le sem az uralkodói, sem pedig a szülői tekintély előtt. Az ezekben a példákban használt bai 拜 szó a teljes tiszteletet kifejező leborulást jelenti, amelyet a muszlimok tehát az Ég (Allah) előtt megtesznek, de földi uralkodó előtt nem.

„Nem borulnak le az állam uralkodója vagy a szülők tekintélye előtt." (JXJ [193.15a]: 不拜國王父母之尊。)

39 Lényegében ugyanez a mondat megjelenik Wu Jian 1350-es mecset-feliratán (Qingjingsi ji) is: „Ezért a legnagyobb tisztelettel szolgálják az Eget, és nem állítanak képmásokat" (故事天至虔, 而無像設). 
„Azt mondják, hogy saját országukban kizárólag az Égi Szellemet imádják [előtte borulnak le], és még ha a királlyal találkoznak, akkor sem borulnak le elötte." (JTS [198.36b]: 自云在本國惟拜天 神, 雖見王亦無致拜之法。)

„Országukban kizárólag az Eget imádják [előtte borulnak le], és amikor a királlyal találkoznak, előtte nem borulnak le.” (XTS [221B.24a]: 國人止拜天, 見王無拜也。)

\subsection{A Nagy Mecset és a Kába-szentély}

A Kábával (Fangzhang 方丈 [LDD], Kai’abai 愷阿白 [YSL, XFZ, XCD], Tianfang 天方 [YSL, MSH, SZL]) és az azt körülvevő Nagy Mecset (alMaszdzsid al-Harám, al-Masjid al-Harām) épületével kapcsolatban kivételesen részletes, sok konkrétumot tartalmazó leírásokat találunk a kínai forrásokban (ezek megbízhatósága természetesen egy másik kérdés). Nem kétséges, hogy az YSL leírásának készítőjét, Ma Huant mind az építészeti megoldások, mind az ezt körülvevő szokások lenyügözték. ${ }^{40}$

„Ha egy jó félnapnyi távot teszünk még meg, akkor elérkezünk az Égi Csarnok szertartási templomába [Nagy Mecset]. Ezt a csarnokot az ö idegen nyelvükön Kai’abai-nak [Kába] nevezik. Kívül fal veszi körbe, amelyen 466 kapu található, a kapuk két oldalán fehér drágakövekből készített oszlopok (állnak), összesen 467 darab: elöl 99 darabot számlálhatunk, hátul 101 darabot, a bal oldalán 132 darabot, a jobb oldalán pedig 135 darabot. A csarnokot [a Kába-szentélyt] ötszínü kőből rakták, négyzet alakú, a teteje lapos. A belsejében öt agarfából készült gerenda és aranyból készült galéria, a csarnok belső falait agyag és rózsavíz, illetve ámbra összekeverésével készítették, így megállás nélkül illatozik. A teteje fekete selyemlepellel van beborítva, a csarnok ajtaját pedig két általuk nevelt, fekete oroszlán őrzi. Minden év 12. hónapjának 10. napján a különböző vidékek muszlimjai, még ha egy- vagy kétévnyi távolságban laknak is, eljönnek, hogy a csarnokban [a Nagy Mecsetben] vegyenek részt a szertartáson. Mindegyikük emlékül levág egy darabot a selyemből, és elviszi magával. Mikor a

40 Függetlenül attól, hogy saját maga valóban járt-e Mekkában. 
levágás miatt elfogy a lepel, az állam uralkodója a már előzetesen megszött lepellel (újra) befedi, és ez minden évben így történik vég nélkül. A [Kába] csarnokától balra van Simayi [Iszmácíl] pátriárka sírja, a sírját zöld sabuni-drágakőből ${ }^{41}$ készítették. (A sír) hosszúsága egy zhang ${ }^{42}$ és két chi $^{43}$ [kb. 3,6 m], magassága három chi $[\mathrm{kb} .90 \mathrm{~cm}]$, szélessége öt chi [kb. 1,5 m]. A sír falát bíborszínű topáz ${ }^{44}$ kövekböl rakták, a magassága több mint öt chi $[\mathrm{kb} .1,5 \mathrm{~m}]$. A [Nagy Mecset] falain belül a négy sarokban négy tornyot [,pagodát”] építettek. ${ }^{45}$ Minden alkalommal, amikor szertartás van, akkor (valaki) felmegy a toronyba [minaretre], és kiáltva a szertartásra hív. A két oldalon, jobbra és balra mindenütt különböző pátriárkák és tanítók emelvénye áll, melyeket szintén kövekböl emeltek, és gyönyörüen feldíszítettek." (YSL [100101]: 再行大半日之程, 到天堂禮拜寺, 其堂番名愷阿白。外週 垣有城, 有四百六十六門, 門之兩傍皆用白玉石為柱, 共有四百 六十七箇。前計九十九箇, 後計一百一箇, 左計一百三十二箇, 右計一百三十五箇。其堂以五色石壘砌，四方平頂樣。內用沉香 木五條為梁，採以黃金為閣，滿堂內牆壁皆是薔微露、龍涎香和 土為之，馨香不絕。上用㿝紵絲為罩蓋之，蓄二黑獅守其堂門。 每年十二月十日, 各番回回人一、二年遠的, 也到堂內禮拜, 皆 將所罩紵絲割收一塊為記，念念而去。剜割既盡，其國王預織其 罩覆罩之，年年不絕。堂之左有司馬儀祖師之墓，其墳壠是綠撒 不泥寶石為之，長一丈二尺，高三尺，闊五尺。為墳之牆，以紺 黃玉壘砌, 高五尺餘。城內四角造四塔, 每禮拜, 即登塔叫禮。 左右兩傍有各祖師傳法之堂, 亦以石頭壘造, 整飾華麗。 $)^{46}$

41 Tao Zongyi 陶宗儀 1366-os Chuogeng lu 輟耕錄 (,,Feljegyzések a szántás befejeztével”) című műve alapján Breitschneider (1910b: 174. n.502): „szappan-zöld”, halványzöld színü, alacsonyabb minőségű smaragdkő perzsa nevének kínai átírása, vö. még Watt 1979: 71-72. A kései középkorban a zhang kb. 3 métert jelentett.

43 A kései középkorban a chi kb. $30 \mathrm{~cm}$-t jelentett.

44 A különböző verziókról lásd Sonnendecker 2005: 183. n. 867.

45 Ez a négy minaret viszonylag jól látható egy 1495-ben írt ún. Nizāmī-kézirat miniatúráján (Ettinghausen 1934: Abb. 13, British Museum), illetve egy 1761-es kéziraton (Abb. 17, Museum für Völkerkunde), de perzsa miniatúrákon például csak egy-egy látszik belöle (Simpson 2010: 139. Fig. 2, 142. Fig. 3).

46 Néhány apróságtól eltekintve lényegében ugyanez a szöveg található meg az XFZben és a XCD-ben. XFZ [天方國]: 再行半日到天堂禮拜寺, 堂番名愷阿白, 其 週如城。有四百六十六門, 兩傍以白玉石爲柱, 共四百六十七柱。其在前者 九十九, 後一百單一, 左一百三十二, 右一百三十五, 堂制如此。皆以五色 
„A templom négy oldalú, minden oldalán 90 oszlopköz ${ }^{47}$ van, összesen 360, és mindenütt fehér jádéból készült oszlopok, a padlózatot sárga gránitból készítették. A csarnokot ötszínű kőből rakták, négyzet alakú, a teteje lapos. A belsejében összesen öt nagy agarfából készült gerenda található, és aranyból készült galéria. A csarnok belső falait mindenütt agyag és rózsavíz, illetve ámbra összekeverésével készítették. Az ajtót két fekete oroszlán őrzi. A [Kába] csarnokától balra van Simayi [Iszmá‘íl] sírja, az abban az országban lakók a szent ember sírjának nevezik. Az alapját mind drágakövek alkotják, a (sírt) körbevevő falakat pedig gránit. A két oldalon, jobbra és balra mindenütt különböző pátriárkák és tanítók emelvénye áll, melyeket szintén kövekből emeltek, és rendkívül gyönyörüek. Ilyen az általuk hitt és gyakorolt iszlám vallás.” (MSH [332.33b-34a]: 寺分四方，每方九十間， 共三百六十間, 皆白玉為柱, 黃甘玉為地。其堂以五色石砌成, 四方平頂。內用沉香大木為梁凡五, 又以黃金為閣。堂中垣墉, 悉以薔薇露、龍涎香和土為之。守門以二黑獅。堂左有司馬儀 墓, 其國稱為聖人塚。土悉寶石, 圍牆則黃甘玉。兩旁有諸祖 師傳法之堂, 亦以石築成, 俱極其壯麗。其崇奉回回教如此。)

„A templom négyoldalú, minden oldalán 90 oszlopköz van, összesen 360, mindenütt fehér drágakőből készült oszlopokkal, a padlózatot sárga gránitból készítették. Középen egy fekete kő van, amely oldalan-

石輳爲方而頂平, 內以沉香木爲梁, 以黃金爲承漏。墻壁皆薔薇露、龍涎香 和土爲之, 上用㿝紵絲爲罩, 畜二黑獅子守堂門。每年十二月十日, 諸番回 回行一二年遠路者到寺禮拜。及去, 往往割皇蓋少許爲記。剜割既盡, 王復 易以新罩, 歲以爲常。堂近有司馬儀聖人之墓在焉。其墳家用綠撒不泥寶石 爲之, 長一丈二尺, 高三尺, 闊五尺。四圍墻垣皆以泔黃玉砌壘, 高五六尺 餘。墻內四隅造四塔, 每禮拜師登塔叫禮。左右兩傍有各祖師傳法之堂, 其 堂亦以石砌造, 皆極華麗。XCD [23.C7]: 其禮拜之寺曰天堂。其堂四方而高 廣, 謂之愷阿白。以黃金爲佛像, 以玉爲座, 堂之周如城, 以五色石壘砌。 城之門四百六十有六。其堂以沉香爲梁, 梁有五。以黃金爲閣, 以泔黃玉布 地, 以薔薇露、龍涎香日塗堂之四壁, 馨香不絶。以白玉爲柱, 柱凡四百六 十有七。前之柱九十有九, 後之柱一百有一, 左之柱一百三十有二, 右之柱 一百三十有五。其堂之幔以紵絲, 色用皇。其守堂獅子二, 色咸黑。他國至 堂而焚香也, 歲一至, 不遠萬里而來, 以十二月十日爲期, 每年此日, 諸國 回回人雖海行一二年遠道者, 亦至此堂禮拜, 皆割取堂內皇幔一方去爲記憶 。盡, 則王又以幔代之。其堂之左有古佛墓, 是爲緑撒卜泥寶石之所築。其 長一丈二尺, 高三尺, 廣五尺。其墓之垣砌以泔黃玉, 高五尺。其城四隅咸 有寶塔, 禮拜者登焉。有授法之堂, 皆五色石爲之。

47 A jian 間 két oszlop közötti egységet jelöl. 
ként több mint három méter. Azt mondják, hogy a Han-kor elején [i. e. 2. sz.] az égből esett le. ${ }^{48}$ A templom(ok) emeletes(ek) és maga$\mathrm{s}(\mathrm{ak})$, a pagoda formájához hasonlatos(ak). ${ }^{49}$ " (XSL [後集/天方國]: 其寺分爲四方，每方九十間，共三百六十間。皆白玉爲柱，黃 甘玉爲地, 中有黑石一片, 方丈餘, 曰漢初天降也。其寺層次高 上, 如塔之狀。)

„Ez [Mekka] az a hely, ahol Mohamed, a szent ${ }^{50}$ született, és itt van, ahol a Kába, ahol ez a szent ember lakott. (A Kábát körülvevő) falakat és termeket ötszínü ${ }^{51}$ drágakővel díszített téglákból építették. Minden évben, amikor a Szent halála elérkezik, a muszlim országok uralkodói mind embereket küldenek, hogy azok drágaköveket, aranyat és ezüstöt adományozzanak, és brokáttal, selyemmel fedjék be a Kábát. Minden évben számos országból eljönnek, hogy tiszteletüket tegyék a Kábánál, más országok hivatalnokaival és előkelőivel együtt, a nagy távolság ${ }^{52}$ sem akadályozza őket, mindannyian eljönnek, hogy megtekintsék és tiszteletüket tegyék.” (LDD [2b-3a]: [麻嘉國] 此是佛麻 霞勿出世之處，有佛所居方丈，以五色玉結甃成牆屋。每歲遇佛 忌辰，大食諸國王皆遣人持寶貝金銀施捨，以錦綺蓋其方丈。每 年諸國前來就方丈禮拜，手他國官豪，不拘萬里，皆至 瞻禮。) $)^{53}$

A fenti leírásokban a vallási csarnok/mecset (tang 堂) szó gyakori használata miatt néha nem egyértelmü, hogy a Nagy Mecsetről vagy az annak udvarában álló Kába-szentélyről van szó. Az első beszámoló (YSL) szerzője Kábának nevezi a Nagy Mecsetet, amelynek belső udvarán áll a Kába-szentély. A szövegek egyrészt leírják a sok bejáratot és az azok mellett álló oszlopokat. Beszélnek a fekete lepelről (kiszva, kiswah), amelyet valóban évente (korábban egyes kalifák gyakrabban) cseréltek. A mecset ámbrával illatozó

48 Ugyanez megtalálható a Mingshiben is: 有黒石, 方丈餘, 曰: 漢初天降也 (MSH 332.5a), illetve Lu Ji 陸楫 Gujin shuohai 古今說海 (20.8) című müvében (1544).

49 Minden bizonnyal a többi forrásban is pagodaként említett, de toronynak (minaretnek) fordítandó építményekröl van szó.

50 A kínai szövegben végig buddha ( $f o$ 佛) szerepel a szent, szent ember helyett.

51 Különböző színü.

52 A kínaiban „tízezer li” (wanli 萬里), körülbelül $5000 \mathrm{~km}$.

53 Lényegében ugyanez található a ZFZ-ben (A.30a): [麻嘉國]乃佛麻霞勿所生之處, 佛居用五色玉甃成。每歲遇佛忌辰, 大食諾國皆至瞻禮, 爭持金銀珍寶以施, 仍用錦綺覆其居。 
falainak leírása első olvasásra a mesék világába tartozik, de Ibn Battúta (Ibn Batțūṭah, 1304-1368/69) beszámol arról, hogy 1398-ban egy általános tisztítás keretében mósusszal és ámbrával kenték be a falakat. ${ }^{54} \mathrm{Az}$ XSL-ben szerepel a 'fekete kő' (heishi 黑石), de annak mérete el van túlozva, hiszen a különböző történeti leírások legfeljebb egy méterben adják meg az egyik oldalát, ugyanakkor a 'fekete kő' nem vonatkozhat az egész szentélyre sem, mert az viszont jóval hosszabb. A kínai szövegek említik továbbá a közismert tényeket a Kábához történő zarádoklatról (haddzs, hajj), amelynek időpontja valóban a muszlim naptár 12. holdhónapjának 8-10. napjára esik (dzú 'l-hiddzsa, dhū'l-hijjah), illetve szó esik az imára hívó adzánról (adhān).

Ábrahám a muszlim hagyomány szerint Hágártól (Hádzsar, Hājar) született gyermekét, Izmaelt (Iszmá 'íl, Ismā '̄il) Mekkába viszi, és később mindkettőjüket a Kába mellett temetik el. Már Ibn Batṭuțah is leírja Iszmácíl sírját: a Kába északi oldalán található, fehéres zöld márványkő borítja, ${ }^{55}$ a neve Hidzsr Iszmá‘íl (Hijr Ismā‘̄il) vagy al-Haṭīm. A Kába mellett a mai napig egy félkör alakú rész van elkerítve, ahová a zarándokok a Kába körüljárásakor (circumambulatio, țawāf) nem lépnek. ${ }^{56}$

\subsection{Mohamed}

A Nagy Mecsethez hasonlóan szintén viszonylag sok forrás említi Mohamedet (Muhammad, Maxiawu 麻霞勿 [ZFZ, LDD, YYZ], Mahama 馬哈麻 [MSH, XFZ, YSL], Mohanmode 謨罕驀德 [MSH, XCD]), ${ }^{57}$ de itt is előtérbe kerülnek az érdekességgel szolgáló elemek, mint például Mohamed sírja.

Elsőként néhány általános kijelentés hangzik el, amelyek (az MSH-leszámítva) röviden Mekkával kapcsolják össze Mohamed vallásalapító tevékenységét.

„Volt itt egy szent, a neve Mohamed.” (ZFZ [A.27]: 有佛名麻霞勿) „Mekka állama: a muszlimok alapító pátriárkája itt kezdte meg vallása tanainak hirdetését. Az itt élők a mai napig mind betartják tanításának előírásait, azok szerint cselekszenek, nem merik megszegni őket.

\footnotetext{
54 Wensinck [- Jomier] 1997: 317b, Jost 2008: 107-108.

55 Gibb 1958: 196, Tresso 2008: 153.

56 Wensinck [- Jomier] 1997: 318a.

57 A már említett Baizizan című versben Muhanmode 穆肎默德 szerepel.
} 
(YSL [99]: 默加國。其回回祖師始於此國闡揚教法, 至今國人悉 遵教規行事, 不敢有違。)

„Egykor nyugaton egy szent ember ezen a helyen [Mekka] kezdte hirdetni az iszlám tanait, az itt élők a mai napig mind betartják tanításának elöírásait, szabályait.” (XFZ [天方國]: 昔者西方聖人始於此 處闡揚回回教法, 至今國人悉遵教門規矩。)

„Úgy mondják, hogy egykor abban az országban [Medina] született Mohanmode, csodálatos képességekkel, ${ }^{58}$ a nyugati terület országait mind meghódította, és (ezekben) az országokban Bu'annuo'er-ként [Payghambar, ${ }^{59}$ próféta] tisztelik, ahogy mi azt mondjuk, hogy 'égi küldött' ['az Ég (Allah) küldötte'].” (MSH [332.34a-b] [Medina] 相傳, 其初國王謨罕驀德生而神靈, 盡臣服西域諸國, 諸國尊 為布按諾爾, 猶言天使也。)

A kínai források helyesen állítják, hogy Mohamed Mekkában született, de három forrás (LDD, YYZ, MSH) tévesen helyezi a sírját is Mekkába, mivel az Medinában (Modina 暮底納) található, és erről másik három forrásnak (XFZ, YSL, XCD) tudomása is van. A sírral kapcsolatban a források elöszeretettel térnek ki az ott tapasztalható csodás fényjelenségre és az ehhez kapcsolódó szokásokra.

„Ez [Mekka] az a hely, ahol Mohamed, a szent ${ }^{60}$ született, és itt van, ahol a Kába, ahol ez a szent ember tartózkodott. [...] A Kába mögött található a szent ember [Mohamed] sírja, amelynél nappal és éjjel is mindig ragyogó fény világít, annyira, hogy az ember nem képes megközelíteni, csak úgy tud odamenni, ha a szemét behunyva elfut mellette. Ha valaki élete végéhez közeledve vesz a síron található földből, és azt a melléhez dörzsöli, akkor, azt mondják, a szent erejénél fogva a

58 Az itt használt kifejezés (sheng er shenling 生而神靈) a klasszikus kínai forrásokban a Sárga Császárral kapcsolatban jelenik meg legtöbbször, továbbá előfordul a Wu Jian által 1350-ben írt mecsetfeliratban is.

59 A payghambar perzsa szó, prófétát jelent. Ugyanebben a kontextusban, de más átírásban szerepel a payghambar név a Li Xian 李賢 (et al.) által szerkesztett [Da] Ming yitong zhi [大]明一統志 (SKQS ed.: 90.25b) földrajzi enciklopédiában: Bie’anba'er 別諳拔爾 (utána a szöveg megjegyzi: „kínai nyelven ‘égi küldöttnek' mondjuk [華言天使]”.

${ }^{60}$ A kínai szövegben végig buddha ( $f o$ 佛) szerepel a szent vagy szent ember helyett. 
mennyországba kerül. ${ }^{61 ”}$ (LDD [2b-3a] [麻嘉國]: 此是佛麻霞勿出 世之處, 有佛所居方丈。 $[. .$.$] 方丈後有佛墓, 日夜常見霞光,$ 人近不得, 往往皆合眼走過。若人臨命終時, 取墓上土塗胸, 師 乘佛力超生云。 $)^{62}$

„Ennek az államnak [Mekka] a földjén született a csodálatos Mohamed, akit szentnek neveztek. A templom mögött található a csodálatos sírja, amely nappal és éjjel is mindig fényben úszik, senki sem képes megközelíteni, ezért szemüket becsukva futnak el mellette.” (YYZ [麻嘉 國]: 其國是土神麻霞勿出世處, 稱神為佛, 廟後有神墓, 日夜常 有光, 人不敢近, 皆合眼而走過也。)

„Azt mondják, hogy a muszlim vallás alapítóját Mohamednek [Mahama] nevezték, fóleg ezen a vidéken [Mekka] terjesztette tanítását, és amikor meghalt, itt temették el. A sír fejénél mindig fény látható, sem nappal, sem éjszaka nem marad abba. Az utána jövők követték tanításait, régóta nem hanyatlik (a vallásuk), ezért az emberek barátsággal viseltetnek egymás iránt.” (MSH [332.33a-b] [默加國]: 相傳回 回設教之祖曰馬哈麻者, 首於此地行教, 死即葬焉。墓頂常有 光, 日夜不熄。後人遵其教, 久而不衰, 故人皆向善。)

„Ha egy napig tovább megyünk nyugatra, ${ }^{63}$ akkor egy városhoz érkezünk, amelyet az ő idegen nevükkel Modinának [Medinának] neveznek. A városban található Mahama [Mohamed], a szent ember sírja. A sír a mai napig ragyogó fényt bocsát ki magából, éjjel-nappal egészen a felhőkig emelkedve.” (XFZ [天方國], YSL [103]: 又往西行 一日到一城, 番名驀底納。城中馬哈麻聖人陵寢在焉。至今墓上 發毫光, 日夜侵雲而起。)

„Medina városa: a várostól keletre található Mohamed [Mohanmode] sírja, amelynek fejénél ötszínü fényt (látni), sem hajnalban, sem estére

${ }^{61}$ Az eredetiben egy jellegzetes buddhista kifejezés áll: „A buddha erejénél fogva születik újjá (a Tiszta Földön)” (cheng foli chaosheng 乘佛力超生).

62 Lényegében ugyanez a szöveg jelenik meg a ZFZ Mekkáról szóló részében (A.30a): 後有佛墓, 畫夜常有霞光, 人莫能近, 過則合眼。若人臨命終時, 摸取墓上 土塗胷, 云可乘佛力超生。

63 Vö. Mills 1970: 177. n. 5: „The statement of direction and distance is wrong; in truth, Medina lies some 300 miles north of Mecca, and the journey by caravan takes about 10 days." 
nem szünik meg a ragyogása.” (XCD [23.C7/Medina]: 驀底納城。 城之東日謨罕驀德神人之墓。墓頂有五色光, 旦夕輝煌不絶。

Érdemes megjegyezni, hogy a Mohamed név egyik kínai átírásában (Maxiawu 麻霞勿) szerepel az az írásjegy, amelyet a sírjánál található fényjelenség leírására használnak (ZFZ, LDD: xia 霞, a nap felkelését és lenyugvását kísérő ragyogás). Az állandóan világító fényen kívül néhány kínai forrás egy másik legendás elemet is Mohamed sírjához köt:

„Mohamed sírja mögött van egy kút, a vize tiszta és édes. Aki tengerre kel, az feltétlenül mer belőle és magával viszi, mert ha viharba kerülne, és ezt a vizet szétszórja (a vihar irányába), akkor az lenyugszik." (MSH [332.34a]: [Mekka] 馬哈麻墓後有一井, 水清而甘。 泛海者必汲以行, 遇風風, 取水灑之即息。)

„(Mohamed) sírja mögött van egy kút, az idegen nyelvükön Abisansan, az íze tiszta és édes. A helybeliek odajárnak, hogy vegyenek belőle és a hajójukra tegyék, mivel ha viharba kerülnek, akkor ezt a vizet szétszórva a vihar és a hullámok (is) azonnal elcsitulnak." (XFZ [天方國]: 墓後有井, 番名阿必糝糝, 味清甘。番人往往取 水置舡中，遇風風作，以水灑之，風浪頓息。)

„(Mohamed) sírja mögött van egy kút, a vize tiszta és édes, Abi-sansannak nevezik. A helybeliek vesznek belőle és a hajójukon elraktározzák, mivel ha a tengeren átkelve viharba kerülnek, akkor ezt a vizet szétszórva a vihar és a hullámok (is) azonnal elcsitulnak." (YSL [103]：墓後有一井水, 水清甜, 名阿必糁糁。番之人取其水藏 船內, 過海倘遇風風, 即以此水洒之, 風浪頓息。)

„(Mohamed) sírja mögött van egy forrás, a neve Abi-sansan. Az íze édes és finom. Ez a forrás képes lenyugtatni a hullámokat. Aki tengerre kel, az feltétlenül mer belőle és magával viszi, mert ha viharba kerülne, és ezt a vizet szétszórja (a vihar irányába), akkor a hullámok lecsitulnak.” (XCD [23.C7/Medina]: 墓後有泉, 其名阿必糁糝。 其味甘美, 其泉能息波濤, 泛海者必汲藏於舟, 遇風風而灑之 也，波濤隨息。） 
Az itt említett forrás ismét egy perzsa szó átírása: Ab-i Zamzam (Zamzam vize), azonban nem Medinában, hanem Mekkában található. ${ }^{64}$

\section{Összefoglalás}

A fenti tanulmány célja egyrészt az volt, hogy bemutassa, milyen sok mindent tudtak, illetve nem tudtak a középkori Kínában az egyébként Kína számára sok szempontból fontos muszlim országok vallásáról. Általában elmondható, hogy a kínai történeti és földrajzi források (az ilyen jellegü kínai hagyományoknak megfelelően) sok konkrét adatot (számokat, neveket stb.) sorolnak fel, mégis más országok szokásaiban és vallásában (jelen esetben az iszlámban) hangsúlyozottan keresték az egzotikumot. Megjegyezték, hogy a nők eltakarják arcukat, hogy a muszlimok nem fogyasztanak alkoholt, hogy nem tisztelik az uralkodót, vagy nem esznek disznóhúst; részletesen leírták a lenyügöző Nagy Mecsetet és a Kába-szentélyt, Iszmácíl és Mohamed sírját, valamint a hozzájuk kapcsolódó hiedelmeket, mivel mindezek „furcsaságnak”, „exoticának” számítottak a kínai kultúrához képest. Pusztán ezen részletek alapján a kínai olvasónak nehéz lehetett eldöntenie, hogy az iszlám mely jellemzői fontosak és melyek marginálisak. Habár a beszámolók szerzői meglehetősen objektív hangnemet ütnek meg végig, de az iszlámra vonatkozóan még az egyébként muszlim Ma Huan esetében sem kapunk koherens, egységes, szerves leírást, hanem elsősorban érdekességek gyüjteményét, amely izgalmas és néha meglepően pontos, de pusztán kiragadott példákon keresztül néhány aspektust nagyít fel, míg alapvető jellemzőkről alig szól.

Az utalások többségének pontosságából úgy tünik azonban, hogy a kínai szem számára érdekes leírások többsége valamilyen konkrét tényen alapul, és a szerzők semmilyen szinten nem kívánták ezeket túlzottan a mesék világába utalni. Ezt már csak azért sem tehették, mivel a leírások többsége egyrészt közvetlen tapasztalaton (Du Huan [8. sz.], Ma Huan [15. sz.], Gong Zhen [15. sz.], Fei Xin [15. sz.]) vagy ezek mérsékelt átdolgozásán alapult, másrészt mivel nagyon is gyakorlati célokat szolgáltak. A kínai szempont tehát nem a korabeli kínai szemléletnek az iszlám világára történő rávetítésében (mint pl. az ókori Shanhaijing 山海經 esetében) érvényesült, hanem elsősorban a fenti leírásokban szereplő, illetve nem szereplö jelenségek kiválasztásában.

${ }^{64}$ Mills 1970: 177. n.7. A Zamzam-kútról lásd még Hawting 1980. 


\section{Elsődleges források}

Jingxingji 經行記 [Du Huan 杜環] (SKQS ed.)

Jiu Tangshu 舊唐書 [Liu Xu 劉昫 és Zhang Zhaoyuan 張昭遠] (SKQS ed.)

Lingwai daida 嶺外代答 [Zhou Qufei 周去非] (SKQS ed.)

Mingshi 明史 [Xu Yuanwen 徐元文, Zhang Tingyu 張廷玉 et al.] (SKQS ed.)

Shuyu zhouzi lu 殊域周咨錄 [Yan Congjian 嚴從簡] (Xu Sili 余思黎 (ed.) 2000. Yan Conjian: Shuyu Zhouzi lu 嚴從簡: 殊域周咨錄. [中外交通史籍叢刊, 13] Beijing: Zhonghua Shuju.)

Xin Tangshu 新唐書 [Ouyang Xiu 歐陽修 és Song Qi 宋祁] (SKQS ed.)

Xingcha shenglan 星槎勝覽 [Fei Xin 費信] (online ed.: https://zh.wikisource.org/wiki/ 星槎勝覽/卷2, utoljára megtekintve: 2017.12.07.)

Xiyang chaogong dianlu 西洋朝貢典錄 [Huang Xingzeng 黃省曾] (online ed.: https:// zh.wikisource.org/wiki/西洋朝貢典錄/卷下, utoljára megtekintve: 2017.12.07.)

Xiyang fanguo zhi 西洋番國志 [Gong Zhen 琿珍] (online ed.: https://zh. wikisource. org/wiki/西洋番國誌, utoljára megtekintve: 2017.12.07.)

Yingya shenglan 瀛涯勝覽 [Ma Huan 馬歡]: Wan Ming 万明 (ford., jegyz.) 2005. Ming chaoben Yingya shenglan jiaozhu 明钞本《瀛涯胜览》校注. Beijing: Haiyang Chubanshe.

Yiyuzhi 異域志 [Zhou Zhizhong 周致中] (online ed.: https://zh.wikisource.org/wiki/ 異域誌, utoljára megtekintve: 2017.12.07.)

Zhufanzhi 諸蕃志 [Zhao Rugua 趙汝适] (SKQS ed.)

\section{Másodlagos szakirodalom}

Akin, Alexander 1999-2000. „The Jing Xing Ji of Du Huan: Notes on the West by a Chinese Prisoner of War." Harvard Middle Eastern and Islamic Review 5: 77-102.

Ben-Dore Benite, Zvi 2005. The Dao of Muhammad: a Cultural History of Muslims in Late Imperial China. Cambridge, Mass. and London: Harvard University Asia Center.

Boga István - Prileszky Csilla 1964. Ibn Battúta zarándokútja és vándorlásai. Budapest: Gondolat Kiadó.

Bretschneider, E. 1910a/b. Mediaeval Researches from Eastern Asiatic sources: fragments towards the knowledge of the geography and history of Central and Western Asia from the 13th to the 17th century. I-II. London: Kegan Paul, Trench, Trübner \& Co. Ltd.

Erie, Matthew S. 2016. China and Islam. The Prophet, the Party, and Law. Cambridge: Cambridge University Press.

Ettinghausen, Richard 1934. „Die bildliche Darstellung der Ka'ba im Islamischen Kulturkreis." Zeitschrift der Deutschen Morgenländischen Gesellschaft 87/3-4: 111-137.

Gade, Anna M. 2006. „Recitation.” In: Andrew Rippin (ed.) The Blackwell Companion to the Qur'ān. Oxford: Blackwell Publishing, 481-493. 
Gibb, H. A. R. (trans. and ed.) 1958. The Travels of Ibn Battūtata, A.D. 1325-1354 (Volume 1). London: Hakluyt Society.

Goitein, S. D. 1991. „Djum‘a.” In: B. Lewis, Ch. Pellat, J. Schacht (eds.) The Encyclopaedia of Islam (New Edition), vol. II. Leiden: E. J. Brill, 592-594.

Hawting, G. R. 1980. „The Disappearance and Rediscovery of Zamzam and the 'Well of the Ka'ba'." Bulletin of the School of Oriental and African Studies 43/1: 44-54.

Hirth, Friedrich - Rockhill, W. W. (trans.) 1911. Chau Ju-Kua: His Work on the Chinese and Arab Trade in the twelfth and thirteenth Centuries, entitled Chu-fan-chï. St. Petersburg: Printing Office of the Imperial Academy of Sciences.

Hu, Fan 2008. Der Islam in Shaanxi: Geschichte und Gegenwart Mit einer Untersuchung zum islamisch-christlichen Dialog in Zeiten der Globalisierung und des Ökumenismus. (PhD diss., Rheinischen Friedrich-Wilhelms-Universität, Bonn)

Israeli, Raphael 1978. Muslims in China: A Study in Cultural Confrontation. London: Curzon.

Israeli, Raphael 1994. Islam in China: A Critical Bibliography. Westport, Conn.: Greenwood Press.

Jost, Alexander 2008. Hoher Besuch im Land des Himmelsplatzes Die Fahrten der MingFlotte in die Arabische Welt 1413 - 1433. (MA szakdolgozat, Eberhard-Karls-Universität Tübingen)

Leslie, Donald D. 1986. Islam in Traditional China: A Short History. Canberra: Canberra College of Advanced Education.

Leslie, Donald D. 1987. „Living with the Chinese: the Muslim Experience in China, T'ang to Ming." In: Charles Le Blanc - Susan Blader (eds.) Chinese Ideas about Nature and Society: Studies in Honour of Derk Bodde. Hong Kong: Hong Kong University Press, 175-193.

Long, Darui 2000. „A Note on the Hongwu Nanzang, a Rare Edition of the Buddhist Cannon." The East Asian Library Journal 9/2: 112-147.

Mills, J. V. G. 1970. Ying-yai Sheng-lan: 'The Overall Survey of the Ocean's Shores' [1433]. Cambridge: Cambridge University Press.

Mills, J. V. G. (trans., annot.) - Ptak, Roderich (rev.) 1996. Hsing-ch'a Sheng-lan: The Overall Survey of the Star Raft by Fei Hsin. Wiesbaden: Harrassowitz Verlag.

Neuwirth, Angelika 2006. „Verse(s).” In: Jane Dammen McAuliffe (general editor) Encyclopaedia of the Qur'ān. Vol. V. Leiden - Boston: Brill, 419-429.

Oláh Csaba 2000. „Az iszlám megjelenése és elterjedése Kínában.” Hamar I. (szerk.) Mitoszok és vallások Kinában. [Sinológiai Mühely 1.] Budapest: Balassi Kiadó, 123-139.

Pelliot, Paul 1933. „Les grands voyages maritimes chinois au début du XVe siècle.” T'oung Pao [Second Series] 30/3-5: 237-452.

Petersen, Kristian 2017. Pilgrimage, Scripture, and Language in the Han Kitab. Oxford: Oxford University Press.

Plessner, M. 1995. „Ramaḍān.” In: B. Lewis, Ch. Pellat, J. Schacht (eds.) The Encyclopaedia of Islam (New Edition), vol. VIII. Leiden: E. J. Brill, 417-418.

Pulleyblank, Edward G. 1991. Lexicon of Reconstructed Pronunciation in Early Middle Chinese, Late Middle Chinese, and Early Mandarin. Vancouver: UBC Press. 
Qutbuddin, Tahera 2008. „Khuṭba. The Evolution of Early Arabic Oration.” In: Beatrice Gruendler (ed.) Classical Arabic Humanities in Their Own Terms Festschrift for Wolfhart Heinrichs on his 65th Birthday Presented by his Students and Colleagues. Leiden: Brill, 176-273.

Simon Róbert 1987a. Korán. Budapest: Helikon Kiadó.

Simon Róbert 1987b. A Korán világa. Budapest: Helikon Kiadó.

Simon Róbert 2009. Iszlám kulturális lexikon. Budapest: Corvina.

Simpson, Marianna Shreve 2010. „From Tourist to Pilgrim: Iskandar at the Ka'ba in Illustrated Shahnama Manuscripts." Iranian Studies 43/1: 127-146.

Sonnendecker, Klaus 2005. Huang Xingzeng: Verzeichnis der Akteneinträge zu Audienzen und Tributen vom Westlichen Meer (Xiyang chaogong dianlu) [黃省曾, 西洋朝貢典錄, 1520 n. Chr.], (annotierte Übersetzung). (PhD disszertáció, Freie Universität, Berlin)

Szombathy, Zoltán 2018. „A Korán szövege és a rituális tisztaság.” In: Déri Balázs - Kósa Gábor - Vér Ádám (szerk.) Purum et immundum. Az Eötvös Loránd Tudományegyetem Bölcsészettudományi Karán 2016. október 14-15-én tartott vallástudományi konferencia elöadásai. Budapest: Eötvös Loránd Tudományegyetem Bölcsészettudományi Kar, Vallástudomány Központ (megjelenés előtt).

Tresso, Claudia M. 2008. Ibn Battuța: I viaggi. Torino: Einaudi.

Wain, Alexander 2016. „Islam in China: The Hān Kitāb Tradition in the Writings of Wang Daiyu, Ma Zhu and Liu Zhi, with a Note on Their Relevance for Contemporary Islam." Islam and Civilisational Renewal 7/1: 27-46.

Watt, J. C. Y. 1979. „Notes on the Use of Cobalt in Later Chinese Ceramics.” Ars Orientalis 11: 63-85.

Wensinck, A. J. 1986. „Khuțbah.” In: B. Lewis, Ch. Pellat, J. Schacht (eds.) The Encyclopaedia of Islam (New Edition), vol. V. Leiden: E. J. Brill, 74-75.

Wensinck, A. J. 2000. „Tarāwīh.” In: B. Lewis, Ch. Pellat, J. Schacht (eds.) The Encyclopaedia of Islam (New Edition), vol. X. Leiden: E. J. Brill, 222.

Wensinck, A. J. [- J. Jomier] 1997. „Ka‘ba.” In: B. Lewis, Ch. Pellat, J. Schacht (eds.) The Encyclopaedia of Islam (New Edition), vol. IV. Leiden: E. J. Brill, 317-322. 